ECOLOGICA, Vol. 28, No 104 (2021), 643-650

https://doi.org/10.18485/ecologica.2021.28.104.21

Originalni naučni rad

UDC: 330.142

336.71

\title{
Banking approach to natural capital risk
}

\section{Rizici prirodnog kapitala u bankarstvu}

\author{
Jozefina Beke-Trivunac ${ }^{1 *}$, Jelena Krpić ${ }^{2}$ \\ 1,2ALFA BK University, Faculty of finance, banking and auditing, Belgrade, Serbia / \\ Univerzitet ALFA BK, Fakultet za finansije, bankarstvo i reviziju, Beograd, Srbija \\ ${ }^{*}$ Corresponding author
}

Received: 19.10.2021, Accepted: 20.11.2021.

\begin{abstract}
This paper aims to identify how banks define natural capital, how they prioritize natural capital risks in their policies, and how they approach them. The article analyzes the presentation of relevant data in banks' integrated reports. The selected sample includes eighteen integrated reports for 2020 included in the International Integrated Reporting Council (IIRC) $<\mid R>$ Examples database. Banks' definitions of natural capital vary, from the bank as a consumer of natural resource to the nature as the fundament for human life. Assessment of risk priority, measured by banks' appetite for the relevant UN SDGs, reveals that almost all banks focus on SDG 13: Climate action, as the material issue in the banking business. Banks recognize that they are exposed to natural capital risk indirectly through their funding activities. This exposure is fundamental to their funding policies and gives them a pivotal role and significant responsibilities concerning the climate change issue.
\end{abstract}

Keywords: Definition of natural capital, SDGs in banking, direct and indirect risks in banking.

Sažetak: Ovaj rad ima za cilj da identifikuje kako banke definišu pojam prirodnog kapitala, koji prioritet u svojim politikama daju riziku prirodnog kapitala i kakav je njihov pristup upravljanju tim rizicima. $U$ tekstu se razmatra prikaz relevantnih podataka navedenih u integrisanim izveštajima banaka. Odabrani uzorak uključuje osamnaest integrisanih izvještaja za 2020. godinu uključenih u bazu primera Međunarodnog saveta za integrisano izvještavanje (IIRC) $<\mid R>$. Definicije prirodnog kapitala banaka variraju od banke kao potrošača prirodnih resursa, pa do prirode kao osnove za ljudski život. Procena prioriteta rizika, merena posvećenošću banaka relevantnom SDG-u UN-a, pokazuje da se gotovo sve banke usmeravaju na SDG 13: Klimatske akcije, kao materijalno pitanje u bankarskom poslovanju. Banke prepoznaju da su svojim aktivnostima finansiranja indirektno izložene riziku od prirodnog kapitala. Ova izloženost je fundamentalna za njihovu politiku finansiranja i daje im ključnu ulogu i značajne odgovornosti po pitanju klimatskih promena.

Ključne reči: Definicija prirodnog kapitala, ciljevi održivog razvoja u bankarstvu, direktni i indirektni rizici prirodnog kapitala u bankarstvu.

10rcid.org/0000-0002-7394-7006, e-mail: jozefina.beke@live.com

2orcid.org/0000-0002-4675-7987, e-mail: keyagency28@gmail.com 


\section{INTRODUCTION}

As projected in the World Economic Forum Global Risk Report 2020, environmental risks continue to dominate the top ten significant global risks list in both impact and likelihood. These risks include extreme weather events, human environmental damage, biodiversity loss, natural resource crisis, and climate action failure (World Economic Forum, 2021). Climate change is at the top of these risks, resulting in considerable economic, environmental, and social costs.

Banks have already recognized that they have a pivotal role and primary responsibilities concerning the climate change issue "because they can guide loans and investments towards businesses that are environmentally virtuous and work from a perspective of improved awareness and containment of risks" (Fideuram, 2021). Banks engage in various global groups, organizations, and activities to keep their role prominent and report on their objectives and performance in managing natural capital risks, as univerzalition of values imposes on business the requirement to approach possible problems in advance. This paper aims to identify how banks define natural capital, how they prioritize natural capital risks in their policies, and how they approach them.

\section{MATERIALS AND METHODS}

The research analyzes banks' presentation of natural capital and natural capital risks and their management approach to these risks in their integrated reports. "An integrated report should disclose information about matters that substantively affect the organization's ability to create value over the short, medium, and long term". It shows, among other issues, "how the organization tailors its business model and strategy to respond to its external environment, and the risks and opportunities it faces" (IIRC, 2021). Determining the materiality in most cases is based on the GRI materiality principles (GRI, 2021). According to these principles, this type of report should cover aspects that reflect the organization's significant economic, environmental, and social impacts and/or substantively influence the assessments and decisions of stakeholders (Bank Australia, 2021). In addition to these principles, for this paper, United Nation Foundation Sustainable Development Goals (SDG) (United Nations Foundations, 2015), which banks follow in their policies, are recognized as the indicators of material topics.

The sample includes eighteen integrated reports for 2020 included in the International Integrated Reporting Council (IIRC) Integrated reporting Examples database: http://examples.integratedreport ing.org/reporters?start=S.
In addition to the information presented in integrated reports, many banks prepare supplementary announcements about environmental and climate risks and sustainability issues. This information was not the subject of the analysis.

\section{RESULTS AND DISCUSSION}

First, we analyzed the banks' definitions of natural capital to understand their assumption, especially to recognize whether banks rewrite the standard definition of natural capital given in the International $<\mathrm{IR}>$ Framework or have their own view of this issue. Then, we analyzed the banks' approach to UN Sustainable development goals (SDG) to assess the materiality of natural capital risk bank by bank. Finally, we analyzed the banks' approach to natural capital risks.

\section{Definition of natural capital}

The International Integrated Reporting Framework (Framework) defines capitals as "stocks of value that are increased, decreased or transformed through the activities and outputs of the organization" (IIRC, 2021). Natural capital is defined as "all renewable and non-renewable environmental resources and processes that provide goods or services that support an organization's past, current or future prosperity. It includes air, water, land, minerals and forests, and biodiversity and ecosystem health" (IIRC, 2021) Practical issues impose the need to modify this definition in order to customize it to individual bank circumstances and policies. The research recognized the respective bank's definition of natural capital in seven reports. These definitions follow the general definition given in the Framework but include additional specifications and intentions.

Three definitions specify the bank as the consumer of nature:

"Natural capital comprises set of processes and environmental resources, both renewable and otherwise, which contribute to generating goods or services for the Group's business" (Fidearum, 2021).

"The natural resources (such as land, water, and power) we use in our operations and business activities" (DFCC, 2021).

"The direct use and impact on natural resources in our operations, including energy, water and climate, and our influence through our business activities" (Nedbank Group, 2021).

Two definitions specify the bank as the consumer of nature and producer of impacts on the nature:

"The use of natural resources, the bank's contribution to climate change and impact on the environment, including pollution" (ABN AMRO Bank, 2021). 
"Natural capital includes the renewable and nonrenewable environmental resources which are impacted by our operations and business activities" (Capitec Bank Holdings Limited , 2021).

One definition identifies the humans as the consumers of nature:

"The Earth's natural resources and the countless services they provide make human life possible" (UniCredit, 2021).

Another definition identifies the bank and its clients as the consumers of nature:

"We impact the natural environment directly in our operations, as well as indirectly through our customers and suppliers" (DBS Group Holdings Ltd., 2021).

Natural Capital Finance Alliance (NCFA) and PricewaterhouseCoopers in their paper Integrating Natural Capital in Risk Assessments: A step-by-step guide for banks which some banks follow in managing their environmental risk management process, provide the definition oriented toward humans and clearly express economic activity:

"Natural capital is a way of thinking about nature as a stock that provides a flow of benefits to people and the economy. It consists of natural capital assets - such as water, forests, and clean air - that together provide humans the means for healthy lives and enable economic activity" (Natural Capital Finance Alliance and PricewaterhouseCoopers, 2018).

Searching for the most suitable definition of the natural capital useful for the Natural Capital Register, Mace considers that the definition of natural capital should have, among others, two characteristics: (i) it shall have some actual or potential relevance to human welfare, now or in the future; and (ii) is plausibly subject to management by people in some way to restore or recover (Mace at all., 2015). Having this in mind, the definition of an independent Natural Capital Committee, which delineates the values and benefits people get from the natural elements, best suits the purpose of the Register:

"the elements of nature that directly and indirectly produce value or benefits to people, including ecosystems, species, freshwater, land, minerals, the air, and oceans, as well as natural processes and functions" (Natural Capital Committee, 2014).

Most of the presented definitions of natural capital delineate its function as a resource for business activities, and banks' activities impact this resource. But the definitions of UniCredit Bank and the Natural Capital Finance Alliance (NCFA) are rather different and oriented towards human life. Furthermore, the DBS Group Holdings Ltd. definition of natural capital is constructive and suitable for understanding risk factors which expose the bank to natural environmental risks.

\section{UN SDG supported by banks}

All the eighteen banks disclosed their support of UN Sustainable development goals (SDG). The most relevant for a bank are usually those where the bank directly contributes to their realization through landing for investments intended for these goals.

The analysis of the sampled banks' integrated reports reveals that the banks support eight out of seventeen UN SDGs:

SDG 6: Clean water and sanitation,

SDG 7: Affordable and clean energy,

SDG 9: Industry innovation and infrastructure,

SDG 11: Sustainable cities and communities,

SDG 12: Responsible consumption and

production,

SDG 13: Climate action,

SDG 14: Life below water, and

SDG 15: Life on Land.

The majority of the banks, sixteen of them, focus their support on SDG 13: Climate action; ten banks on SDG 7: Affordable and clean energy; seven banks on SDG 11: Sustainable cities and communities and SDG 12: Responsible consumption and production; and six banks on SDG 15: Life on Land. The support of other three goals is not significant.

A list of goals supported by the banks is given in Table 1.

\section{Two types of banks' environmental risk approach}

Although the banks use different definitions of natural capital, their environmental goals and risk management activities show that all of them assess the impact of the natural environment directly through their operations and indirectly through our customers and suppliers in their credit policies. For example, in its report for 2020, DBS declares: "We impact the natural environment directly in our operations, as well as indirectly through our customers and suppliers" (DCSA, 2021, p. 69). Both direct and indirect risks have two facets, physical risk (extreme weather events producing financial damage to premises) and transition risks resulting from the adjustment towards a low carbon economy. Both physical and transition risks could result in the impairment of the bank's clients' asset values, impacting their creditworthiness. There also remains a risk that the level and pace of responses are insufficient to mitigate risk (Lloyds Banking Group, 2021, p. 14). 
Table 1. Overview of SDG goals revealed in the sample of the banks' reports

\begin{tabular}{|c|c|c|c|c|c|c|c|c|c|c|}
\hline & Bank & Country & SDG 6 & SDG 7 & SDG 9 & SDG 11 & SDG 12 & SDG 13 & SDG 14 & SDG 15 \\
\hline 1 & $\begin{array}{l}\text { ABN AMRO Bank NV } \\
\text { (ABN AMRO Bank NV, } \\
\text { 2021, p 43-44) } \\
\end{array}$ & Netherlands & & & & & yes & yes & & \\
\hline 2 & $\begin{array}{l}\text { Bank of Australia } \\
\text { (Bank of Australia, } \\
2021, \text { p. } 80 \text { ) } \\
\end{array}$ & Australia & & yes & Yes & yes & & yes & & yes \\
\hline 3 & $\begin{array}{l}\text { Bank of Ceylon (Bank } \\
\text { of Ceylon, 2021, } \\
\text { p. } 3,58)\end{array}$ & $\begin{array}{c}\text { Ceylon } \\
\text { / } \\
\text { Sri Lanka } \\
\end{array}$ & & yes & & & & yes & & yes \\
\hline 4 & \begin{tabular}{|l|} 
Capitec Bank (Capitec \\
Bank, 2021, p. 3, 58) \\
\end{tabular} & $\begin{array}{l}\text { South } \\
\text { Africa }\end{array}$ & yes & & & & & & & \\
\hline 5 & $\begin{array}{l}\text { Creval (Creval, 2021, } \\
\text { p. 12) }\end{array}$ & Italy & & yes & & yes & yes & yes & & yes \\
\hline 6 & $\begin{array}{l}\text { DBS (DBS Group } \\
\text { Holdings Ltd., 2021, } \\
\text { p. 100) }\end{array}$ & Singapore & & yes & & & yes & yes & & \\
\hline 7 & $\begin{array}{l}\text { DFCC (DFCC, 2021, p. } \\
72)\end{array}$ & Sri Lanka & & yes & & & yes & yes & yes & \\
\hline 8 & $\begin{array}{l}\text { Fidearum (Fidearum, } \\
\text { 2021, p. } 43 \text { ) }\end{array}$ & Italy & & & & & & yes & & yes \\
\hline 9 & $\begin{array}{l}\text { FMO (FMO, 2021, p. } \\
26)\end{array}$ & Netherlands & & & & & & yes & & \\
\hline 10 & \begin{tabular}{|l|} 
Garanti ${ }^{(I I)}($ Garanti \\
BBVA, 2021, p. 58)
\end{tabular} & Türkiye & yes & yes & & & yes & yes & yes & yes \\
\hline 11 & $\begin{array}{l}\text { HSBC Holdings (HSBC } \\
\text { Holdings, 2021, p. 48) }\end{array}$ & $\begin{array}{c}\text { United } \\
\text { Kingdom }\end{array}$ & & & & & & yes & & \\
\hline 12 & $\begin{array}{l}\text { Lloyds }^{(\text {III) }} \text { (Lloyds } \\
\text { Banking Group, 2021, } \\
\text { p. 24)) }\end{array}$ & $\begin{array}{l}\text { United } \\
\text { Kingdom }\end{array}$ & & & Yes & yes & & yes & & \\
\hline 13 & $\begin{array}{l}\text { Mizuho (Mizuho } \\
\text { Financial Group, 2021, } \\
\text { p. 55) }\end{array}$ & Japan & yes & & & & & yes & & \\
\hline 14 & $\begin{array}{l}\text { Nedbank (Nedbank } \\
\text { Group, 2021, p. 35) }\end{array}$ & $\begin{array}{l}\text { South } \\
\text { Africa }\end{array}$ & yes & yes & Yes & yes & yes & & & yes \\
\hline 15 & $\begin{array}{l}\text { Santander (Santander, } \\
\text { 2021, p. 24) }\end{array}$ & Spain & & yes & & yes & & yes & & \\
\hline 16 & DCSA (DCSA, 2021) & $\begin{array}{l}\text { South } \\
\text { Africa }\end{array}$ & & yes & & & & yes & & \\
\hline 17 & $\begin{array}{l}\text { UniCredit(IV) (UniCredit, } \\
2021, \text { p. } 35)\end{array}$ & Italy & & yes & yes & yes & & yes & & \\
\hline \multirow[t]{2}{*}{18} & $\begin{array}{l}\text { Vancity (Vancity, 2021, } \\
\text { p. 14) }\end{array}$ & Canada & & & & & yes & yes & & \\
\hline & Number of banks & & 4 & 10 & 4 & 7 & 7 & 16 & 2 & 6 \\
\hline
\end{tabular}

(I) Creval UN SDGs relate to the activity 'Management of natural resources and reduction of environmental impact';

(II) Garant BBVA UN SDGs relate to the group of 'Sustainability goals';

(III) Lloyds Banking Group UN SDGs relate to 'ESG lending and investment goals.'

(IV) UniCredit UN SDG relates to the group 'Systemic trends.'

Source: Authors

The scale at which banks use natural resources in their operations does not significantly impact natural capital. Banks' environmental policies usually encompass minimizing the impact of their activities on the environment by optimizing resource utilization, complying with environmental legislation that may apply to them, and actively promoting environmental awareness among employees (Dajić et al., 2020).
Two types of risks associated with climate change for a bank are direct, physical, and indirect transition risks. Physical risk is linked to the physical impact of weather events and natural disasters (e.g. floods, earthquakes, and tornadoes). Banks treat these risks as other operational risks (Sovilj, Stoiljković-Zlatanović, 2018) and, following professional guidance, do not assess it as material (Beke-Trivunac, 2021). 
Table 2. Examples of direct and indirect environmental policies presented by the banks

\begin{tabular}{|c|c|c|}
\hline Bank & $\begin{array}{l}\text { Direct contribution by managing } \\
\text { bank's operating activities }\end{array}$ & $\begin{array}{l}\text { Indirect contribution by managing bank's } \\
\text { lending and investment policies }\end{array}$ \\
\hline $\begin{array}{l}\text { Bank of } \\
\text { Australia (Bank } \\
\text { Australia, 2021, } \\
\text { p. 79, 87, 89) }\end{array}$ & $\begin{array}{l}\text { The year } 2020 \text { was the first full year } \\
\text { operating on } 100 \% \text { renewable } \\
\text { electricity. Bank's total gross carbon } \\
\text { emission is reduced by } 10 \text { percent. }\end{array}$ & $\begin{array}{l}\text { - Launched bank's Clean Energy Home Loan with } \\
\text { the investment of up to } \$ 60 \mathrm{~m} \text { from the Clean } \\
\text { Energy Finance Corporation } \\
\text { - Protected } 121,149 \mathrm{~m} 2 \text { of land on the bank's } \\
\text { Conservation Reserve to balance out the impact of } \\
\text { construction loans the bank financed. }\end{array}$ \\
\hline $\begin{array}{l}\text { Bank of Ceylon } \\
\text { (Bank of Ceylon, } \\
2021, \text { p. } 70 \text { ) }\end{array}$ & $\begin{array}{l}2,122 \mathrm{MWh} \text { generation of renewable } \\
\text { energy through solar branches. }\end{array}$ & $\begin{array}{l}\text { Lending to renewable energy projects LKR } 568.7 \\
\text { million. }\end{array}$ \\
\hline $\begin{array}{l}\text { Creval (Creval, } \\
2021, \text { p. } 36,63)\end{array}$ & $\begin{array}{l}\text { Reduction of energy consumption due to: } \\
\text { - } 7 \text { projects for revamping/ } \\
\text { modernization of the HVAC systems (of } \\
\text { which } 1 \text { runs on fuel oil and } 6 \text { on } \\
\text { electricity); } \\
\text { - business travel with hybrid or electric } \\
\text { cars instead of petrol cars; }\end{array}$ & $\begin{array}{l}\text { During 2020, the bank granted 'green' loans } \\
\text { (Radovanović, 2019) involving: the creation of } \\
\text { structures for poultry breeding using organic } \\
\text { methods; photovoltaic systems ...; construction and } \\
\text { refurbishment of buildings involving works that also } \\
\text { include compliance with the regulations on animal } \\
\text { well-being; creation of a water reservoir for water } \\
\text { conservation. }\end{array}$ \\
\hline $\begin{array}{l}\text { HSBC Holdings } \\
\text { (HSBC } \\
\text { Holdings, 2021, } \\
\text { p. } 45,46,51 \text { ) }\end{array}$ & $\begin{array}{l}\text { The bank reports carbon dioxide } \\
\text { emissions resulting from energy use in } \\
\text { the bank's buildings and employees' } \\
\text { business travel. } \\
\text { In } 2020,37.4 \% \text { of the bank's electricity } \\
\text { was renewable [...] } \\
\text { The majority of bank's travel emissions } \\
\text { are concentrated in air travel, which fell } \\
\text { in } 2020 \text { due to the Covid-19 outbreak. } \\
\text { As the majority of bank's emissions are } \\
\text { within its supply chain [...] in } 2020, \text { the } \\
\text { bank began targeting its largest } \\
\text { suppliers, representing } 60 \% \text { of its } \\
\text { annual supplier spend in } 2020 \ldots \\
\end{array}$ & $\begin{array}{l}\text { Bank's sustainability risk policies cover agricultural } \\
\text { commodities, chemicals, defense, energy, forestry, } \\
\text { mining and metals, UNESCO World Heritage Sites, } \\
\text { and Ramsar-designated wetlands. } \\
\text { Where the bank identifies activities that could cause } \\
\text { material negative impacts, it will only provide } \\
\text { finance if it can confirm customers are managing } \\
\text { these risks responsibly. Such customers are subject } \\
\text { to greater due diligence and generally require } \\
\text { additional approval by sustainability risk specialists. }\end{array}$ \\
\hline $\begin{array}{l}\text { Lloyds (Lloyds } \\
\text { Banking Group, } \\
2021, \text { p. } 21,24 \text { ) }\end{array}$ & $\begin{array}{l}\text { The bank has continued to reduce the } \\
\text { energy and carbon intensity of its } \\
\text { properties and has supported low } \\
\text { carbon travel. }\end{array}$ & $\begin{array}{l}\text { The bank has tightened its lending appetite for the } \\
\text { coal sector. }\end{array}$ \\
\hline
\end{tabular}

Source: Authors

The risks that indirectly involve a bank in its role as the funder of companies and individuals who could, in turn, contribute to climate change through their manufacturing activities are known as transition risks. This role emphasizes the responsibility of banks in directing companies towards more virtuous paths from an environmental perspective (Creval, 2021, p. 35). In this sense, banks are developing extensive control and risk management policies for assessing indirect natural capital risks to which they are exposed through their funding activities. These results are incorporated into the loan and investment portfolio risk management framework.

The Natural Capital Finance Alliance (NCFA) developed a methodology that helps the bank quickly access natural capital risk in its portfolio. This natural capital risk assessment process focuses on identifying how businesses depend on the environment, how these dependencies are threatened by environmental change, and the resulting risks for financial institutions (Natural Capital Finance Alliance and PriceWaterHouseCoopers, 2018, p. 3).

\section{The contribution of banks to the sustainable} development

Banks as financial intermediaries can play a significant role in the process of transition to a more energy efficient and environmentally friendly business model. As stated in the text above, banks do not significantly use natural resources in their operations and therefore do not affect natural capital. However, the role of financial intermediary puts them in the position of an indirect participant in the enclosure of natural capital. The green concept of finance includes redefining primary goals, maximizing value for 
shareholders while respecting sustainable development and preserving the environment.

The transition to a green economy brings threats and opportunities for both the economy and the banks. Banks are expected to responsibly finance clients that include banking products and services based on the principle of sustainable development. Banks include the environmental aspect in their business strategy. Experience has shown that one of the most significant risks for banks is credit risk, the risk that the bank's client will not repay the loan in accordance with the agreed terms.

Credit risk methodologies should consider climate change risks. That is, banks should determine how much climate risks affect the risk of default of debtors. As the risk management process is a continuous process, when approving a loan, banks assess the creditworthiness of each client and continue to monitor the client during the placement period, considering its credit rating. In the process of credit risk management, it is necessary to perform a sectoral and geographical analysis. This assume performing an analysis of activities and geographical areas that are characterized by risks related to climate change. For example, a bank's management may have a business strategy and risk appetite, to reduce or limit lending to environmentally harmful sectors. Or real estate that does not have an energy efficiency label will not be taken as collateral.

As an indirect participant in the preservation of natural capital, banks have an important management mechanism - the credit price represented by the interest rate. Interest charges are banks' income. Differentiating the cost of credit for sectors and areas assessed with climate change risks would encourage banks to invest in lower-rated climate change risk investments. For example, bank may provide a more favorable interest rate for financing: cars with reduced emissions, energy efficient real estate, financing projects related to environmental protection, financing projects such as the construction of wind farms, etc.

Climate change risks can affect the value of collateral. Commercial banks are expected to pay attention to the physical location and energy efficiency of commercial and residential real estate. For example, loans that have a mortgage as collateral real estate with an energy efficiency label would have a lower interest rate, because it is considered that the transition risk is lower. Environmentally sustainable funds can be financed with dedicated instruments, for example "green bonds", which have different financing costs. Also, banks can appear as a guarantor of the issue of securities issued to finance eco-projects.
To illustrate banks' climate change risk policies, we selected a few examples disclosed in banks' risk management strategy, which serve as the financial instruments that encourage sustainable development.

\section{Example 1: Lloyds Banking Group}

As part of the Lloyds Banking Group (the Group) credit risk policy, the Group has "mandatory requirements to consider environmental risks in key risk management activities. In Commercial Banking, Relationship Managers must continue to ensure that sustainability risk is considered for all new and renewal facilities, and specifically commented on where credit limits exceed $£ 500,000 "$. The Group has also developed a tool in Commercial Banking to help qualitatively assess its clients' physical and transition risks". In Retail, the Group "considers exposure to physical risks, such as flooding, in our mortgages origination criteria and we have also introduced sustainability related criteria into our motor finance businesses. Within Insurance, an assessment of climate-related risks to General Insurance (GI) liabilities is integrated into the internal model governance process". The Group also developed the weather modelling capabilities through completion of a research partnership between the Group's Gl Weather Modelling Team and the University of Reading on extreme wind and flood risk in the UK (Lloyds Banking Group, 2021).

The Group also provided over £2.3 billion of green finance in Commercial Banking in 2020, through its "Clean Growth Finance Initiative, Commercial Real Estate Green Lending Initiative, Renewable Energy Financing and Green Bond facilitation. This increased its total green finance to over $£ 7.3$ billion since 2016. In addition, the Group has supported clients with over $£ 1.8$ billion of Sustainability Linked Loans since 2017" (Lloyds Banking Group, 2021, p. 16).

\section{Example 2: HSBC}

HSBC has identified six sectors where HSBC is most exposed to transition risk and its level of lending activity in those sectors. HSBC collates information about its customers' climate transition strategies to assess their need and readiness to adapt, and to identify potential business opportunities. This supports HSBC decision making and credit risk management processes. Across 2019 and 2020, HSBC received responses from customers within the six high transition risk sectors, which represented $41 \%$ of HSBC exposure - an increase of seven percentage points from 2019" (HSBC Holdings plc, 2021, p. 19). 
For HSBC "this means making financing decisions with a consideration for climate change and intensifying HSBC support for customers in their transition to lower carbon emissions. In 2017, HSBC pledged to provide and facilitate $\$ 100 \mathrm{bn}$ of sustainable finance and investment by 2025 to support its customers as they switch to more sustainable ways of doing business, and by the end of 2020 HSBC had already achieved $\$ 93.0 \mathrm{bn}$ of that ambition. In October 2020, HSBC set [...] a new target of providing between $\$ 750 \mathrm{bn}$ and $\$ 1$ th in sustainable finance and investment by 2030. HSBC will work with its portfolio of customers to provide expert advice and support them on their transition to lower carbon emissions, while considering the unique conditions for customers across developed and developing economies. To do this, HSBC will increase its portfolio of transition finance solutions to help even the heaviest emitting sectors to progressively decarbonize, while helping to ensure a just and stable transition to maintain economic stability" (HSBC Holdings plc, 2021, p.46).

\section{CONCLUSIONS}

Banks play a prominent role in driving sustainable socio-economic development for the benefit of all stakeholders and creating the future by providing capital for investment in the real economy.

Banks' definitions of natural capital vary, from a very simple one which comprises natural assets which contribute to generating goods and services for banking business and identifies business as the consumer of natural resources, over the definition which regards business as the consumer of natural resources and its impact on nature, to the one which points out natural capital as the fundament of human life.

The materiality of natural capital risk, according to banks' adherence of the UN SDG, show that almost all banks focus on SDG 13: Climate action as the material issue for banking business. SDG 7: Affordable and clean energy, SDG 11: Sustainable cities and communities, SDG 12: Responsible consumption and production, and SDG 15: Life on Land are also considered necessary. Banks randomly supported three other goals in their reports, and we do not consider them significant.

The scale at which banks use natural resources in their operations does not significantly impact natural capital. Banks recognize that they are exposed to natural capital risk indirectly by their funding activities. The realization of these risks can substantially deteriorate their funding portfolios. Banks assess their exposure and develop comprehensive funding policies to manage this exposure, following current global trends.

\section{LITERATURA / REFERENCES}

[1] ABN AMRO Bank NV (2021). Integrated Report 2020. Retrieved August 9, 2021, from:

https://assets.ctfassets.net/1u811bvgvthc/1IHIVd HZhHfAR8ODgWySms/ab7a4883991a87691f057 96a2bea6524/ABN_AMRO__Annual_Report_ 2020.pdf.

[2] Bank Australia (2021). 2020 Impact Report. Retrieved August 20, 2021, from:

https://www.bankaust.com.au/globalassets/assets /reporting-governance--policies/corporate-financial-reports/2020/2020-impact-report-faIr.pdf.

[3] Bank of Ceylon (2021). Annual Report 2020. Retrieved August 17, 2021, from: https://web.boc.lk/assets/reports/annual/BANKOF-CEYLON_Annual-Report-2020.pdf.

[4] Beke-Trivunac Jozefina, (2021). Pojam materijalnost za potrebe pripreme finansijskih izveštaja prema MSFI, Revizor, 24(93), 95-97.

DOI:10.5937/Rev2194089B

[5] Capitec Bank Holdings Limited (2021). Integrated Annual Report 2021. Retrieved August 17, 2021, from: https://www.capitecbank.co.za/globalassets /pages/investor-relations/financialresults/2021/ annualreportintegrated_annual_report_2021.pdf.

[6] Creval (2021). Consolidated non-financial statement 2020. Retrieved August 17, 2021 from: http://www.gruppocreval.com/cartellaPDF/en_pa rsedPDF/en_2021/assemblea190421/DCNF_2020_eng.pdf.

[7] Dajić, Maja, Kojić, Nenad, Dajić, Milan (2020). Specifičnosti modernog menadžmenta u funkciji održivog razvoja, Ecologica, 27(99), 519-524.

[8] DBS Group Holdings Ltd. (2021). Annual Report 2020. Retrieved August 9, 2021, from: https://www.dbs.com/annualreports/2020/files/m edia/dbs-annual-report-2020.pdf.

[9] DCSA (2021). Development Bank of Southern Africa, 2000 Integrated Annual Report. Retrieved August 20, 2021, from: https://www.dbsa.org/ sites/default/files/media/documents/202102/DBSA\%20Integrated\%20Annual\%20Report\% 202019-20.pdf.

[10] DFCC Bank (2021). Annual report 2020, 193. Retrieved August 17, 2021 from: https://s3-apsoutheast-1.amazonaws.com/dfcc.lk/wpcontent/uploads/2021/03/01112634/DFCCBank_Annual-Report_2020_Secured.pdf.

[11] Fidearum - Intesa Sanpaolo Private Banking (2021). Integrated Annual Report 2020. Retrieved August 16, 2021, from: https://www.fideuram.it/media/4160/fideuram_int egrato2020_ita_11052021.pdf. 
[12] FMO (2021). Annual Report 2020. Retrieved August 18, 2021, from:

https://annualreport.fmo.nl/2020/FbContent.ashx /pub_1000/downloads/v210423194036/Annual_ Report_2020_v8252.pdf.

[13] Garanti BBVA (2021). Integrated Annual Report 2020. Retrieved August 18, 2021, from:

https://www.garantibbvainvestorrelations.com/en /images/entegre-faaliyet-raporu-2020/pdf/garantibbva-integrated-annual-report-2020.pdf.

[14] GRI (2020). GRI Standards Glossary 2020. Retrieved August 28, 2021 from:

https://www.globalreporting.org/how-to-use-thegri-standards/gri-standards-english-language/.

[15] HSBC Holdings plc. (2021). Annual Report and Accounts 2020. Retrieved August 18, 2021, from: https://www.hsbc.com/investors/results-andannouncements/annual-report.

[16] International Integrated Reporting Council (IIRC) (2021). International < I.R.> Framework. Retrieved August 19, 2021, from:

https://integratedreporting.org/wp-

content/uploads/2021/01/Internationallntegrated ReportingFramework.pdf

[17] Lloyds Banking Group (2021). Annual Report and Accounts 2020. Retrieved August 18, 2021, from: https://www.lloydsbankinggroup.com/assets/pdfs linvestors/annual-report/2020/2020-lbg-annualreport.pdf.

[18] Mace M. Georgina, Hails S. Rosemary, Cryle Philip, Harlow Julian, Clarke J. Steward (2015). REVIEW: Towards a risk register for natural capital, Journal of Applied Ecology, 52(3), 641-653. Retrieved August 27, 2021, from:

https://besjournals.onlinelibrary.wiley.com/doi/full /10.1111/1365-2664.12431.

[19] Mizuho Financial Group (2021). Integrated report 2020 Annual Review April 2019 - March 2020. Retrieved August 18, 2021, from:

https://www.mizuhogroup.com/binaries/content/a ssets/pdf/mizuhoglobal/investors/financialinformation/annual/data2003/data2003_all.pdf.

[20] Natural Capital Committee (2014). State of Natural Capital: Restoring Our Natural Assets. Natural Capital Committee, London.

[21] Natural Capital Finance Alliance (NCFA) and PricewaterhouseCoopers (2018). Integrating Nat- ural Capital in Risk Assessments: A step-by-step guide for banks. Retrieved August 19, 2021, from: https://naturalcapital.finance/wp-content/uploads /2019/01/NCFA-Phase-2-Report.pdf.

[22] Nedbank Group (2021). Integrated report 2020. Retrieved August 18, 2021, from:

https://www.nedbank.co.za/content/nedbank/desk top/gt/en/investor-relations/informationhub/integrated-reporting.html.

[23] Radovanović, Biljana (2019). Održivi razvoj i ekološko-ekonomski rast, Ecologica, 26(93), 119123.

[24] Santander (2021): Annual report 2020. Retrieved August 16, 2021, from: https://www. santander.com/content/dam/santandercom/en/documentos/informe-anual/2020/ia2020-annual-report-en.pdf.

[25] Sovilj Ranko, Stojković-Zlatanović Sanja (2018) Modeli upravljanja operativnim rizikom u investicionim društvima u procesu evropskih integracija republike Srbije, Megatrend revija, 15(2),1-16. DOI: 10.5937/MegRev2102005S

[26] Stevanović D. Miroslav, Đurđević Ž. Dragan (2021). Međunarodno pravo pravo kao činilac savremenog poslovanja, Megatrend revija, 18(2), 5-22.

[27] UniCredit (2021). Integrated Report 2020. Retrieved August 20, 2021, from: https://www. unicreditgroup.eu/content/dam/unicreditgroupeu/documents/en/sustainability/sustainabilityreports/2020/UC_INTEGRATO_2020_ENG.pdf.

[28] United Nations Foundations (2015). The Sustainable Development Goals (SDGs), Retrieved August 2, 2021, from https://unfoundation.org /what-we-do/issues/sustainable-developmentgoals/?gclid=EAlalQobChMlgsD9larx8gIVj5GyC h3wugQREAAYASAAEgKOMPD_BwE.

[29] Vancity (2021). 2020 Annual Report. Retrieved August 18, 2021, from: https://www.vancity.com /SharedContent/documents/AnnualReportArchiv es/Vancity2020annualreport.pdf.

[30] World Economic Forum (WeForum) (2021). The Global Risks Report 2021, 16th Edition, 11-13. Retrieved August 23, 2021, from: https://www3.weforum.org/docs/WEF_The_Global _Risks_Report_2021.pdf. 